\title{
飼料の制限が豚肉脂質および脂肪組織の脂肪酸組成に 及ぼす影響
}

\author{
石田光晴・銅道百里・鈴木啓一*・清水俊郎* \\ 宮城県農業短期大学，仙台市太白区旗立，982-0215 \\ *宮城県畜産試験場, 宮城県岩出山町, 989-6445
}

(1999 年 7 月 5 日受付)

\begin{abstract}
要 約 飼料の制限が豚肉脂質および脂肪組織に及ぼす影響について検討した。ランドレースメ大 ヨークシャーメデュロック（LWD） 6 頭を 1 区として, 飼料給与量別に不断給餌 (100\%) 区, 不断給餌 の $80 \%$ 制限および $60 \%$ 制限区の 3 区に分け，之殺 24 時間後に第 12,13 胸椎に位置する胸最長筋（ロー ス）を採取した。ロース，皮下脂肪，筋間脂肪の脂肪酸組成およびコレステロールの含量を測定した。 ロース脂肪含量は 3 区ともほぼ同様の値を示し, 飼料給与量の違いによる影響は認められなかった。 ロース全脂質脂肪酸では，100\%区から 60\%区にかけてパルミトオレイン酸とリノール酸は低下した が，他の脂肪酸には差がなかった。ロース中性脂質脂肪酸組成では，3区の脂肪酸はほぼ同様の值を示し 影響はみられなかったが，ロース極性脂質では，ミリスチン酸，パルミチン酸，パルミトオレイン酸， リノール酸, 不飽和度に有意差 $(\mathrm{P}<0.01)$ が得られた。コレステロール含量は, $100 \%$ 区，80\%区，60\% 区の順に高い值を示したが有意差はなかった。さらに，食肉市場で正常または軟脂と判定された去勢豚 4 頭（LWD）をそれぞれ 1 区として，ロース，皮下脂肪，腎臓脂肪の脂肪酸組成およびコレステロール の含量を測定した。ロース脂肪含量は，軟脂区が正常区よりやや低い值であったが有意差はなかった。 ロース全脂質の脂肪酸組成では，軟脂区のオレイン酸とリノール酸が有意 $(\mathrm{P}<0.05)$ に高く，軟脂の発 生原因と推測された。コレステロールは, 軟脂区は正常区より顕著に低く, 有意差 $(\mathrm{P}<0.01)$ が得られ た。
\end{abstract}

\section{緒言}

豚肉の脂質性状, 特に脂肪酸の変動要因として, 肉用 豚の品種, 系統, 性などの遺伝的要因と月齢, 体重など の生理的要因, 飼料, 環境温度, 制限給餌, 疾病やス卜 レスなどの環境的要因があげられるが，これらの要因が 互いに重複して影響している。

この中の飼養環境では, 制限給䬺と環境温度の影響が 大きい。一般的には，栄養水準の低下に結びつくような 飼料給与量の制限は脂肪の性状に影響を与える。制限給 餌によって体脂肪の蓄積が遅くなるとともに, 脂肪酸の パルミチン酸 (C16:0) 含量が減少し,オレイン酸 (C
18:1) 及びリノール酸 (C 18:2) 含量が増えて脂肪が軟 化する ${ }^{1 \sim 4)}$ 。しかし，筋肉内脂肪への影響はほとんどない という報告がある ${ }^{5)}$ 。また，豚が飼育される環境温度が 上がると, 脂肪のヨウ素価は減少し, 飽和脂肪酸が多い 硬い脂肪となり，冬季のような気温が低い場合には，不 飽和度が大きくなり脂肪は軟らかくなる ${ }^{6)}$ 。環境温度が 低い場合には，適温条件と比べてェネルギーの消費が激 しくなり，適温時と同一の飼料給与量では脂肪組織へ配 分されるエネルギー量は低下し，結果的には制限給䭒己 比べて見かけ上似た条件になり，脂肪性状に影響を与え るあのと推測される。

本研究では, 肥育用飼料の給与量を変えて, 従来よく

Effects of Feed Restriction on Fatty Acid Composition of Meat and Adipose Tissues in Pig

M. IshidA, Y. Doudou, K. Suzuki* and T. Shimizu*

Miyagi Agricultural College, 2-2-1 Hatatate, Sendai-shi 982-0215

* Miyagi Prefectural Animal Industry Experimental Station, Iwadeyam-cho, Miyagi-ken 989-6445, Japan. 
研究されている脂肪組織だけでなく，食肉としての豚肉 の脂質栄養性（脂肪酸組成とコレステロール含量）に及 ぼす影響を調べた。さらに，枝肉市場で正常豚肉と軟脂 豚肉と判定されたものの違いを明らかにし，制限給慨と の関連性について検討した。

\section{材料および方法}

\section{1. 試料の採取}

実験 1 宮城県畜産試験場で飼育されたランドレース 雌豚に大ヨークシャー雄豚を交配した F1 雌豚 (LW) に デュロック種雄を交配して生産した LWD 去勢豚 6 頭を 1 区として，体重が $30 \mathrm{~kg}$ に達してから $100 \mathrm{~kg}$ を越える まで, 給与量別に 3 区を設け，それぞれの生体重, 枝肉 重量, 枝肉歩留, と体重, ロース長, と体幅, 皮下脂肪 厚などの枝肉成績を得て，屠殺 24 時間後に第 12,13 胸 椎に位置する胸最長筋（ロース芯）とその周囲の脂肪組 織を採取した。供試豚は単飼，自由飲水とし，肥育前期

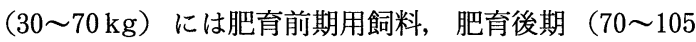
$\mathrm{kg}$ ）には肥育後期用飼料を給与した。実験区分は，対照 区は不断給餌（100\%）とし，試験区として不断給餌の $80 \%$ 量および $60 \%$ 量を給与する $80 \%$ 区および $60 \%$ 区 を設定した。給与飼料量は前報7) の不断給餌による摂食 量を基にして各区の飼料給与量を設定し，実際の飼料摂 食量を表 1 に示した。なお，と畜時の生体重は，食肉市 場に出荷した場合を考慮していずれの区とあ $105 \mathrm{~kg}$ 前 後とした。

実験 2 宮城県内の食肉市場 (3 月に出荷) で正常豚及 び軟脂豚と格付された LWD 去勢豚各 4 頭ずっ，第 12 , 13 胸椎に位置する胸最長筋（ロース）とその周囲の脂肪 組織を採取した。

\section{2. ロース芯全脂質の抽出と分画}

ロース芯試料 $20 \mathrm{~g}$ を精秤しクロロホルム：メ夕ノ一 ル混液 $(2: 1 \mathrm{v} / \mathrm{v})$ によって全脂質を得た $\left.{ }^{8}\right)$ 。次いで, ク ロロホルム $5 \mathrm{~m} l$ を加えて全脂質を溶解し, ねじ口試験 管に移して冷蔵保存した。得られた全脂質をシリカゲル クロマトグラフ（ミリポア社，セップバック $500 \mathrm{mg}$ ）に よって中性脂質と極性脂質に分画した。
3. 脂肪酸メチルエステルの調製とコレステロールの 抽出

皮下脂肪内層および外層, 筋間脂肪, ロース芯の全脂 質，分画した中性脂質および極性脂質に $5 \%$ 硫酸メ夕 ノールを $5 \mathrm{ml}$ 加え, $90^{\circ} \mathrm{C}, 5$ 時間加熱した。それぞれ冷 却後, 生理的食塩水 $5 \mathrm{~m} l$ と石油エーテル $2 \mathrm{~m} l$ を加えて よく振り, 分離後の石油エーテル層の一部をガスクロマ トグラフに供した。コレステロールの抽出は, 全脂質試 料に $1 \mathrm{~N}$-水酸化力リウム・エ夕ノール溶液を $5 \mathrm{ml}$ 加 え, $90^{\circ} \mathrm{C}, 1$ 時間加熱した。ケン化後, 蒸留水 $5 \mathrm{ml}$, 石油 エーテル $2 \mathrm{~m} l$ を加えてよく振り, 靜置して分離させた。 $5 \alpha$-コレスタンを内部標準物質として加え， ガスクロマ トグラフ分析に供した。

\section{4. ガスクロマトグラフィーの条件}

脂肪酸分析には, 水素炎イオン化検出器 (FID) 付き日 立 G-3000 型ガスクロマトグラフを用いた。カラム充填 剂は DB-WAX $(0.3 \mathrm{~mm} \times 30 \mathrm{~m}$ ガラスキャピラリーカ ラム), 検出器の温度 $300^{\circ} \mathrm{C}$, カラム温度 $210^{\circ} \mathrm{C}$ 恒温, キャリアーガスの種類と流速は窒素, $30 \mathrm{ml} /$ 分とした。 コレステロールの分析は, 水素炎イオン化検出器 (FID) 付き日立 263-30 型ガスクロマトグラフを用いた。カラ ム充填剤は $5 \%$ シリコン GE SE-30クロモソルブ W $\mathrm{AW}-\mathrm{DMCS}(3 \mathrm{~mm} \times 1 \mathrm{~m}$ ステンレスカラム), 検出器の 温度 $300^{\circ} \mathrm{C}$, カラム温度 $250^{\circ} \mathrm{C}$ 恒温, キャリアーガスの 種類と流速は窒素, $30 \mathrm{ml} /$ 分とした。

\section{5. 重量の計算方法}

各脂肪酸及びコレステロールの面積を半值巾法で測定 し，標準物質の面積と比較した。得られた割合をSAS にて分散分析を行った。

\section{結果および考察}

\section{1. 枝肉成績（実験 1)}

各区の枝肉成績を表 2 に示した。終了体重が $105 \mathrm{Kg}$ 以上になるまでの総平均日齢は $100 \%$ 区 176.2 日，80\% 区 205.0 日，60\%区 233.7 日，飼料制限開始後の肥育日 数は 96.0 日，126.0 日，154.2 日となり，それぞれ $100 \%$ 区から 60\% 区にかけて増加し有意差 $(\mathrm{P}<0.01)$ が認め

表 1. 一日平均飼料摂取量 ( $\mathrm{kg} /$ 日)

\begin{tabular}{|c|c|c|c|}
\hline & \multirow{2}{*}{$\begin{array}{c}\text { 不断給餌区 } \\
100 \%\end{array}$} & \multicolumn{2}{|c|}{ 制限給䭒区 } \\
\hline & & $80 \%$ & $60 \%$ \\
\hline 肥育前期（30～70 kg） & $1.99 \pm 0.32$ & $1.73 \pm 0.03$ & $1.44 \pm 0.02$ \\
\hline 肥育後期 $(70 \sim 105 \mathrm{~kg})$ & $3.43 \pm 0.27$ & $2.46 \pm 0.10$ & $2.53 \pm 0.56$ \\
\hline 全期間（30～105 kg） & $2.65 \pm 0.25$ & $2.11 \pm 0.07$ & $1.92 \pm 0.16$ \\
\hline
\end{tabular}


表 2. 制限給餌豚の枝肉成績 ; 実験 1

\begin{tabular}{|c|c|c|c|}
\hline & \multirow{2}{*}{$\frac{\text { 不断給餌区 }}{100 \%}$} & \multicolumn{2}{|c|}{ 制限給餌区 } \\
\hline & & $80 \%$ & $60 \%$ \\
\hline 全飼育日数（日） & $176.2 \pm 12.3 \mathrm{~A}$ & $205.0 \pm 13.0 \mathrm{~B}$ & $233.7 \pm 5.4 \mathrm{C}$ \\
\hline 制限給餌日数（日） & $96.0 \pm 11.9 \mathrm{~A}$ & $126.0 \pm 9.0 \mathrm{~B}$ & $154.2 \pm 7.2 \mathrm{C}$ \\
\hline 屠殺時生体重（kg） & $106.9 \pm 2.4$ & $107.7 \pm 1.0$ & $106.1 \pm 1.2$ \\
\hline 屠殺後体重（kg） & $103.3 \pm 3.0$ & $104.1 \pm 1.7$ & $103.5 \pm 1.3$ \\
\hline 枝肉歩留まり（\%） & $76.6 \pm 1.3$ & $75.9 \pm 1.1$ & $75.3 \pm 0.9$ \\
\hline 屠体長（cm） & $93.7 \pm 3.1 \mathrm{~A}$ & $98.6 \pm 3.4 \mathrm{~B}$ & $98.6 \pm 1.8 \mathrm{~B}$ \\
\hline 屠体幅（cm） & $36.0 \pm 1.0$ & $36.6 \pm 1.0$ & $36.4 \pm 1.0$ \\
\hline ロース長 (cm) & $50.1 \pm 2.4 \mathrm{~A}$ & $54.3 \pm 2.9 \mathrm{~B}$ & $55.0 \pm 2.2 \mathrm{~B}$ \\
\hline
\end{tabular}

平均值士標準偏差 $\mathrm{A}, \mathrm{B}$; 異符号間で有意差あり $(\mathrm{P}<0.01)$

られた。これは, 飼料給与量の違いによって豚の発育速 度が遅くなったことによる。と体重は約 $103.5 \mathrm{~kg}$, 歩留 は 75.3\%〜 76.6\% となり，ほとんど差はなかった。と体 長は $93.7 \mathrm{~cm} \sim 98.6 \mathrm{~cm}$, と体巾は $36.0 \mathrm{~cm} \sim 36.6 \mathrm{~cm}$, ロース長は $50.1 \mathrm{~cm} \sim 55.0 \mathrm{~cm}$ となり，と体長とロース長 において，100\%区と $80 \%$ 区および $60 \%$ 区の間で有意 に増加し $(\mathrm{P}<0.01)$, 飼料摂取量の影響が認められた。

2. ロース芯全脂質およびコレステロール含量 (実験 1)

ロース芯試料の脂肪含量とコレステロール含量を表 3 に示した。脂肪含量は $2.88 \%$ 2.97\% となり 3 区ともほ ぼ同様の值を示しており，飼料摂取量の違いによる影響 は認められなかった。コレステロール含量は，100\%区 は平均 $61.58 \mathrm{mg} / 100 \mathrm{~g}, 80 \%$ 区は $84.11 \mathrm{mg}, 60 \%$ 区は $95.30 \mathrm{mg}$ となり，100\%区，80\%区，60\%区の順に平均 值は高い值を示したが，有意差は得られなかった。この 傾向は実験 2 とは異なっており, 飼料摂取と生体内のエ ネルギー消費および脂質合成の関係について，さらなる 研究が望まれる。

\section{3. 脂肪酸組成 (実験 1 )}

ロース全脂質, 中性脂質および極性脂質の脂肪酸組成 を表 4-1 に，筋肉間脂肪，皮下脂肪内層および外層の各 脂肪酸組成を表 4-2 に示した。ロース全脂質では，主な 脂肪酸であるパルミチン酸は $24.37 \%$ 25.63\%，ステア リン酸 $13.64 \%$ 14.14\%，オレイン酸 $48.56 \%$ 50.25\%, リノール酸 $5.30 \%$ 8.32\%であった。リノール酸とパル ミトオレイン酸には, $100 \%$ 区と他の区の間に有意差 $(\mathrm{P}$ （0.01）が認められた。100\%区から 60\%区にかけてパ ルミトオレイン酸とリノール酸は低下しているが，他の 脂肪酸や不飽和度は 3 区ともほぼ同じ值を示した。U/S 比は 1.49〜1.55 となり有意差は得られなかった。中性脂 質では，主な脂肪酸であるパルミチン酸は $24.44 \%$
$26.21 \%$ ，ステアリン酸 $13.45 \%$ 13.86\%，オレイン酸 $50.23 \%$ 52.10\%, リノール酸 $4.16 \%$ ．88\% であった。 各脂肪酸は 3 区ともほぼ同じ值を示し有意差がなく，飼 料給与量の違いによる影響は認められなかった。極性脂 質では，ミリスチン酸 $1.06 \%$ ～ $2.44 \%$ ，パルミチン酸 $24.41 \%$ 27.74\%，パルミトオレイン酸 $1.47 \%$ 2.54\%, リノ一ル酸 $37.33 \% \sim 40.02 \%$, 不飽和度 $57.14 \%$ $59.59 \%$ であった。これらはいずれあ有意差 $(\mathrm{P}<0.01)$ が 認められた。全脂質とは異なり，パルミチン酸は $100 \%$ 区から 80\%区にかけて低下し，80\%区から60\%区にか けて増加していた。不飽和度の $100 \%$ 区と 60\%区はほ ぼ同様な值を示し，100\% 区と 80\% 区および $60 \%$ 区の 間に有意差があり，80\%区が最も高い值を示し，飼料給 与量の違いによる影響が認められた。

筋肉間脂肪では， ミリスチン酸 $1.20 \% \sim 1.69 \%$, パル ミチン酸 $22.64 \%$ ～ $26.65 \%$, オレイン酸 $44.22 \%$ $45.44 \%$ ，リノール酸 $9.28 \% \sim 14.14 \%$ ，不飽和度 $55.05 \%$ 〜 61.09\%, U/S 比 1.23〜 1.57 であった。これらに有意差 $(\mathrm{P}<0.01)$ が認められ, 飽和脂肪酸は $100 \%$ 区と $60 \%$ 区 の間で低下していき, 不飽和脂肪酸は逆に増加した。皮 下脂肪内層では，パルミチン酸 $22.58 \% \sim 25.40 \%$ ， ステ アリン酸 $14.27 \%$ ～18.00\%，オレイン酸 $44.81 \%$ $47.50 \%$ ，リノール酸 $9.13 \% \sim 12.84 \%$ ，不飽和度 $55.21 \%$ 〜 61.95\%, U/S 比 1.25〜 1.64 であった。飽和脂肪酸は 100\%区と 60\% 区の間では低下し，不飽和脂肪酸は増加 した。パルミチン酸, ステアリン酸, 不飽和度およびU/ $\mathrm{S}$ 比において有意差（P<0.01）が認められた。100\%区 と $80 \%$ 区では，ほぼ同様な值を示したが，100\%区と 60\% 区および 80\% 区と 60\% 区の間でそれぞれ有意差 $(\mathrm{P}<0.01)$ があり, 飼料給与量の違いによる影響が認め られた。皮下脂肪外層では，ミリスチン酸は $1.39 \%$ 
表 3. ロース全脂質およびコレステロール含量 ; 実験 1

\begin{tabular}{|c|c|c|c|}
\hline & \multirow{2}{*}{$\frac{\text { 不断給餌区 }}{100 \%}$} & \multicolumn{2}{|c|}{ 制限給慨区 } \\
\hline & & $80 \%$ & $60 \%$ \\
\hline 全脂質（\%) & $2.95 \pm 1.19$ & $2.79 \pm 1.39$ & $2.88 \pm 0.65$ \\
\hline コレステロール（mg/100g) & $61.58 \pm 26.73$ & $84.11 \pm 35.73$ & $95.30 \pm 43.66$ \\
\hline
\end{tabular}

平均值士標準偏差

表 4-1. ロース脂肪酸組成 ; 実験 1

\begin{tabular}{|c|c|c|c|}
\hline \multirow{2}{*}{ 脂肪酸組成 } & \multirow{2}{*}{$\frac{\text { 不断給餌区 }}{100 \%}$} & \multicolumn{2}{|c|}{ 制限給䭒区 } \\
\hline & & $80 \%$ & $60 \%$ \\
\hline \multicolumn{4}{|l|}{ 全脂質 } \\
\hline C $14: 0$ & $1.52 \pm 0.39$ & $1.31 \pm 0.09$ & $1.59 \pm 0.37$ \\
\hline C $16: 0$ & $25.63 \pm 1.54$ & $24.63 \pm 0.37$ & $24.37 \pm 1.01$ \\
\hline C $16: 1$ & $3.42 \pm 0.44 \mathrm{~A}$ & $2.75 \pm 0.41 \mathrm{~B}$ & $2.96 \pm 0.19 \mathrm{~B}$ \\
\hline C $18: 0$ & $13.64 \pm 1.38$ & $14.14 \pm 0.91$ & $13.37 \pm 0.94$ \\
\hline C $18: 1$ & $50.25 \pm 1.96$ & $48.56 \pm 1.52$ & $49.75 \pm 1.36$ \\
\hline C $18: 2$ & $5.30 \pm 1.44 \mathrm{~A}$ & $8.32 \pm 1.27 \mathrm{~B}$ & $7.68 \pm 1.40 \mathrm{~B}$ \\
\hline C $18: 3$ & $0.24 \pm 0.09$ & $0.30 \pm 0.11$ & $0.29 \pm 0.07$ \\
\hline T.U. & $59.21 \pm 3.01$ & $59.93 \pm 0.67$ & $60.67 \pm 1.55$ \\
\hline $\mathrm{U} / \mathrm{S}$ & $1.49 \pm 0.21$ & $1.50 \pm 0.04$ & $1.55 \pm 0.10$ \\
\hline \multicolumn{4}{|l|}{ 中性脂質 } \\
\hline C $14: 0$ & $1.57 \pm 0.35$ & $1.50 \pm 0.07$ & $1.52 \pm 0.13$ \\
\hline $\mathrm{C} 16: 0$ & $26.21 \pm 1.53$ & $24.98 \pm 0.74$ & $24.44 \pm 1.24$ \\
\hline $\mathrm{C} 16: 1$ & $3.78 \pm 1.06$ & $2.85 \pm 0.35$ & $3.03 \pm 0.20$ \\
\hline C $18: 0$ & $13.86 \pm 1.19$ & $13.82 \pm 0.75$ & $13.45 \pm 1.05$ \\
\hline $\mathrm{C} 18: 1$ & $50.23 \pm 3.11$ & $50.72 \pm 1.13$ & $52.10 \pm 1.35$ \\
\hline C $18: 2$ & $4.16 \pm 1.12$ & $5.88 \pm 1.32$ & $5.18 \pm 0.91$ \\
\hline C $18: 3$ & $0.20 \pm 0.09$ & $0.26 \pm 0.06$ & $0.29 \pm 0.07$ \\
\hline T.U. & $58.37 \pm 2.68$ & $59.71 \pm 0.82$ & $60.61 \pm 2.00$ \\
\hline $\mathrm{U} / \mathrm{S}$ & $1.41 \pm 0.15$ & $1.48 \pm 0.05$ & $1.54 \pm 0.12$ \\
\hline \multicolumn{4}{|l|}{ 極性脂質 } \\
\hline C $14: 0$ & $1.06 \pm 0.25 \mathrm{~A}$ & $2.44 \pm 0.51 \mathrm{~B}$ & $1.79 \pm 0.19 \mathrm{C}$ \\
\hline $\mathrm{C} 16: 0$ & $27.74 \pm 1.15 \mathrm{Aab}$ & $24.41 \pm 1.75 \mathrm{Ba}$ & $27.15 \pm 2.43 \mathrm{ABb}$ \\
\hline $\mathrm{C} 16: 1$ & $1.47 \pm 0.43 \mathrm{~A}$ & $2.54 \pm 0.52 \mathrm{~B}$ & $2.34 \pm 0.29 \mathrm{~B}$ \\
\hline C $18: 0$ & $14.04 \pm 0.53$ & $13.57 \pm 0.47$ & $13.17 \pm 1.59$ \\
\hline C $18: 1$ & $17.55 \pm 0.68$ & $16.55 \pm 1.06$ & $17.76 \pm 1.81$ \\
\hline C $18: 2$ & $37.47 \pm 2.43 \mathrm{~A}$ & $40.02 \pm 1.54 \mathrm{~B}$ & $37.33 \pm 3.52 \mathrm{AB}$ \\
\hline C $18: 3$ & $0.66 \pm 0.23$ & $0.48 \pm 0.17$ & $0.46 \pm 0.15$ \\
\hline T.U. & $57.14 \pm 1.56 \mathrm{~A}$ & $59.59 \pm 2.35 \mathrm{~B}$ & $57.90 \pm 3.22 \mathrm{AB}$ \\
\hline $\mathrm{U} / \mathrm{S}$ & $1.34 \pm 0.09$ & $1.48 \pm 0.14$ & $1.39 \pm 0.18$ \\
\hline
\end{tabular}

平均値土標準偏差 T.U/; 全不飽和脂肪酸

$\mathrm{U} / \mathrm{S}$ : 全不飽和脂肪酸/全飽和脂肪酸

$\mathrm{A}, \mathrm{B}, \mathrm{a}, \mathrm{b}$; 異符号間で有意差あり（A, B ; P<0.01 a, b ; P<0.05） 
表 4-2. 蓄積脂肪脂肪酸組成; 実験 1

\begin{tabular}{|c|c|c|c|}
\hline \multirow{2}{*}{ 脂肪酸組成 } & \multirow{2}{*}{$\frac{\text { 不断給餌区 }}{100 \%}$} & \multicolumn{2}{|c|}{ 制限給餌区 } \\
\hline & & $80 \%$ & $60 \%$ \\
\hline \multicolumn{4}{|l|}{ 筋肉間脂肪 } \\
\hline C $14: 0$ & $1.69 \pm 0.21 \mathrm{~A}$ & $1.63 \pm 0.41 \mathrm{~A}$ & $1.20 \pm 0.11 \mathrm{~B}$ \\
\hline $\mathrm{C} 16: 0$ & $26.65 \pm 1.22 \mathrm{~A}$ & $25.35 \pm 0.64 \mathrm{~B}$ & $22.64 \pm 0.93 \mathrm{C}$ \\
\hline C $16: 1$ & $1.56 \pm 0.28$ & $1.56 \pm 0.16$ & $1.51 \pm 0.26$ \\
\hline C $18: 0$ & $16.61 \pm 1.78$ & $16.67 \pm 1.03$ & $15.16 \pm 1.48$ \\
\hline $\mathrm{C} 18: 1$ & $44.22 \pm 1.35 \mathrm{ABa}$ & $42.93 \pm 1.58 \mathrm{Ab}$ & $45.44 \pm 1.05 \mathrm{Bb}$ \\
\hline $\mathrm{C} 18: 2$ & $9.28 \pm 1.12 \mathrm{~A}$ & $11.87 \pm 0.66 \mathrm{~B}$ & $14.14 \pm 2.17 \mathrm{C}$ \\
\hline T.U. & $55.05 \pm 2.46 \mathrm{Aa}$ & $56.36 \pm 1.44 \mathrm{Ab}$ & $61.09 \pm 1.72 \mathrm{Bab}$ \\
\hline $\mathrm{U} / \mathrm{S}$ & $1.23 \pm 0.12 \mathrm{~A}$ & $1.30 \pm 0.07 \mathrm{~A}$ & $1.57 \pm 0.12 \mathrm{~B}$ \\
\hline \multicolumn{4}{|l|}{ 皮下脂肪内層 } \\
\hline C $14: 0$ & $1.39 \pm 0.22$ & $1.30 \pm 0.19$ & $1.20 \pm 0.12$ \\
\hline C 16:0 & $25.40 \pm 2.06 \mathrm{~A}$ & $24.79 \pm 1.40 \mathrm{~A}$ & $22.58 \pm 1.95 \mathrm{~B}$ \\
\hline $\mathrm{C} 16: 1$ & $1.28 \pm 0.17$ & $1.22 \pm 0.17$ & $1.61 \pm 0.62$ \\
\hline C $18: 0$ & $18.00 \pm 1.60 \mathrm{~A}$ & $17.25 \pm 1.10 \mathrm{~A}$ & $14.27 \pm 1.07 \mathrm{~B}$ \\
\hline C $18: 1$ & $44.81 \pm 2.46$ & $45.28 \pm 2.25$ & $47.50 \pm 2.51$ \\
\hline C $18: 2$ & $9.13 \pm 1.24$ & $10.67 \pm 1.03$ & $12.84 \pm 3.98$ \\
\hline T.U. & $55.21 \pm 3.77 \mathrm{~A}$ & $57.16 \pm 2.02 \mathrm{~A}$ & $61.95 \pm 2.86 \mathrm{~B}$ \\
\hline $\mathrm{U} / \mathrm{S}$ & $1.25 \pm 0.19 \mathrm{~A}$ & $1.32 \pm 0.10 \mathrm{~A}$ & $1.64 \pm 0.20 \mathrm{~B}$ \\
\hline \multicolumn{4}{|l|}{ 皮下脂肪外層 } \\
\hline C $14: 0$ & $1.42 \pm 0.12 \mathrm{~A}$ & $1.60 \pm 0.43 \mathrm{~A}$ & $1.39 \pm 0.52 \mathrm{~B}$ \\
\hline $\mathrm{C} 16: 0$ & $24.90 \pm 1.52 \mathrm{~A}$ & $23.80 \pm 1.09 \mathrm{~A}$ & $20.52 \pm 0.66 \mathrm{~B}$ \\
\hline $\mathrm{C} 16: 1$ & $1.47 \pm 0.14$ & $1.86 \pm 0.59$ & $1.81 \pm 0.24$ \\
\hline C 18:0 & $15.35 \pm 1.74 \mathrm{~A}$ & $13.45 \pm 1.57 \mathrm{~B}$ & $11.07 \pm 0.80 \mathrm{C}$ \\
\hline C $18: 1$ & $46.84 \pm 1.66 \mathrm{~A}$ & $46.41 \pm 1.78 \mathrm{~A}$ & $49.26 \pm 1.59 \mathrm{~B}$ \\
\hline C $18: 2$ & $10.02 \pm 1.66 \mathrm{~A}$ & $12.90 \pm 2.77 \mathrm{~B}$ & $15.95 \pm 1.78 \mathrm{C}$ \\
\hline T.U. & $58.33 \pm 3.23 \mathrm{~A}$ & $61.16 \pm 1.98 \mathrm{~B}$ & $67.02 \pm 0.96 \mathrm{C}$ \\
\hline $\mathrm{U} / \mathrm{S}$ & $1.41 \pm 0.18$ & $1.58 \pm 0.12$ & $2.03 \pm 0.09$ \\
\hline
\end{tabular}

平均值士標準偏差 T.U/; 全不飽和脂肪酸

$\mathrm{U} / \mathrm{S}$ : 全不飽和脂肪酸/全飽和脂肪酸

$\mathrm{A}, \mathrm{B}, \mathrm{a}, \mathrm{b}$; 異符号間で有意差あり（A, B ; P $<0.01 \quad \mathrm{a}, \mathrm{b} ; \mathrm{P}<0.05 ）$

$1.60 \%$ ，パルミチン酸 $20.52 \%$ 24.90\%，ステアリン酸 $11.07 \%$ 15.35\%，オレイン酸 $46.41 \%$ 49.26\%, リノ一 ル酸 $10.02 \%$ ～15.95\%，不飽和度 $58.38 \%$ ～ $67.02 \%$ で あった。これらに有意差 $(\mathrm{P}<0.01)$ が認められた。全脂 質，皮下脂肪内層と同じように $100 \%$ 区と $60 \%$ 区の間 では飽和脂肪酸が低下し, 不飽和脂肪酸は増加してい た。100\%区と $80 \%$ 区で有意差が認められたのは，ステ アリン酸とリノール酸, $100 \%$ 区と $60 \%$ 区で有意差が認 められたのは, ミリスチン酸, パルミチン酸, ステアリ ン酸，オレイン酸およびリノール酸，80\%区と60\%区 で有意差が認められたのは, ミリスチン酸, パルミチン
酸, ステアリン酸, オレイン酸およびリノール酸であっ た。このように顕著な差は, 飼料摂取量の違いだけでな く, 体表面に近い部位では, 身体深部よりも気温の影響 を受けやすいことから外気温の変動も関係していると考 えられる。

以上のことから，すべての部位において飼料摂取量の 違いによる各脂肪酸組成への影響が認められた。前述し たように，豚にとって栄養水準の低下に結びつくような 給与量の制限は脂肪の性状に影響を与える。制限給餌に よって, 脂肪の蓄積が遅くなるととあにオレイン酸およ びリノール酸含量が増えて, 脂肪は軟化した。すなわち, 
脂肪蓄積量を減少させるほど飼料給与量を抑制すれば， 体脂肪は相対的に不飽和脂肪酸を増し軟化する。これ は，無制限給慨によって飽和脂肪酸優勢である脂肪酸生 合成が低下し, また, 飼料中の油脂の不飽和脂肪酸, 特 にリノール酸の選択的蓄積があり，さらに，エネルギー 不足の時には脂肪組織中の飽和脂肪酸が消費される傾向 にあるため, 全体として飽和脂肪酸が減少し軟化するも のと考えられている99。

本研究では, 飼料給与量を低下させることで, 脂肪組 織だけでなく筋肉内脂肪の不飽和脂肪酸む増加した。こ の場合, 制限給餌区の出荷体重までの肥育期間が不断給 餌区よりも1〜2 カ月延長したため，その影響も考慮し なければならないが，一般にエネルギー給与が充分な場 合の肥育では, 体重増加に伴い飽和脂肪酸の割合が増加 すると言われている。本実験の結果では逆に不飽和脂肪 酸が増加したことから，この期間の延長による影響は小 さかったのではないかと推測される。一方，飼料摂取を 制限した区では，発育成績や枝肉成績を考慮に入れなけ ればならないが, 不断給餌に比較して，オレイン酸やリ ノール酸といった不飽和脂肪酸が増加していることを考 えると, 人への栄養条件を考慮した場合, 軟脂豚となっ て格落ちしなければ不飽和脂肪酸が増加することは望ま しいことになる。なぜなら，近年，不飽和脂肪酸の摄取 が人の循環器系疾患等に有効であることが示されている からである10)。

\section{4. 軟脂豚のロース芯全脂質およびコレステロール含量 (実験 2)}

ロース芯の全脂質とコレステロール含量を表 5 に示し た。正常区の脂肪含量は平均 $2.57 \%$, 軟脂区は平均 $2.24 \%$ となり，軟脂区が正常区よりやや低い値となった が有意差は得られなかった。脂肪含量は, 動物の種類, 組織の違い, 年齢, 飼養条件, と体部位によって異なっ ている。そして, 体脂肪の性状は給与飼料の質や量によ る影響が大きい。分析試料は, 食肉市場で購入したため 給与飼料の質や量, 飼養条件などはわからないが, 正常

表 5. ロース全脂質およびコレステロール含量 ; 実験 2

\begin{tabular}{lcc}
\hline \hline & 正常区 & 軟脂区 \\
\hline 全脂質 $(\%)$ & $2.57 \pm 0.89$ & $2.24 \pm 0.47$ \\
コレステロール & $94.30 \pm 14.90 \mathrm{~A}$ & $37.81 \pm 14.50 \mathrm{~B}$ \\
$(\mathrm{mg} / 100 \mathrm{~g})$ & & \\
\hline
\end{tabular}

平均值士標準偏差 $\mathrm{A}, \mathrm{B}$; 異符号間で有意差あり（P $<0.01)$
豚と軟脂豚における脂肪含量の違いは認められなかっ た。コレステロールは, 正常区は平均 $94.30 \mathrm{mg} / 100 \mathrm{~g}$, 軟脂区は平均 $37.81 \mathrm{mg} / 100 \mathrm{~g}$ となり, 軟脂区は正常区よ り顕著に低く有意差 $(P<0.01)$ が得られた。正常区と軟 脂区における脂肪含量の違いが認められず，この様にコ レステロール含量に顕著な差があるのは脂質の代謝に影 響があったと考えられ，軟脂豚において，コレステロー ルが生体内で充分に合成できなかったのでないかと推測 される。

\section{5. 軟脂豚の脂肪酸組成（実験 2)}

ロース芯の全脂質, 中性脂質および極性脂質の脂肪酸 組成を表 6-1 に, 腎臓周囲脂肪, 皮下脂肪内層および外 層の脂肪酸組成を表 6-2 に示した。ロース全脂質の主な 脂肪酸であるパルミチン酸は正常区で $25.19 \%$, 軟脂区 で $24.54 \%$ ，ステアリン酸 $13.38 \% ， 13.58 \%$ ，オレイン酸 47.90\%，44.26\% およびリノール酸 7.90\%，11.67\% で あった。この中でオレイン酸とリノール酸に有意差（P <0.05）が認められたが, 不飽和度に差がなかった。この ことから, 前述の報告のとおり, 本実験の軟脂豚はリ ノール酸含量が高いことによるあのと考えられた。中性 脂質では，パルミチン酸は正常区で $25.42 \%$, 軟脂区で $25.24 \%$ ，ステアリン酸 $13.34 \% ， 13.05 \%$ ，オレイン酸 $49.25 \%, 47.28 \%$ およびリノール酸 $6.68 \%, 8.79 \%$ であっ た。リノール酸で軟脂区が正常区より高い值を示してい るが，いずれあ有意差は認められなかった。極性脂質で は，ステアリン酸は正常区で $12.58 \%$, 軟脂区で $13.62 \%$, オレイン酸 $19.02 \%, 17.28 \%$, リノール酸 $31.32 \%$, $29.73 \%$ および不飽和度 $81.50 \%, 80.62 \%$ であった。ステ アリン酸は有意差が認められた。しかし, 全脂質では軟 脂豚に多いリノール酸と不飽和度が正常区の方がわずか に高い值を示したことから，極性脂質における軟脂豚と 正常豚の違いは認められなかった。

腎蔵周囲脂肪では，パルミチン酸は正常区で $25.79 \%$, 軟脂豚で $24.70 \%$, リノール酸 $11.28 \%, 14.09 \%$, リノレ ン酸 $0.65 \% ， 0.94 \%$ および不飽和度 $59.65 \% ， 60.95 \%$ で あった。これらの脂肪酸はいずれあ有意差 $(\mathrm{P}<0.01)$ が 認められた。軟脂区が正常区よりも不飽和脂肪酸含量, リノール酸が多く, 軟脂豚之正常豚の違いが顕著に表れ た。皮下脂肪内層では, パルミチン酸は正常区で $24.96 \%$, 軟脂区で $23.73 \%$, リノール酸 $12.31 \%$, $16.03 \%$, リノレン酸 $0.71 \%, 0.93 \%$, 不飽和度 $58.07 \%$, $60.90 \%$ および U/S 比 1.39, 1.60 であった。いずれも有意 差 $(\mathrm{P}<0.01)$ が認められ, 軟脂豚が高い值を示した。ま た, 皮下脂肪外層においても同様な傾向が得られた。腎 臓周囲脂肪と同様に軟脂豚と正常豚の違いが顕著に表れ 
表 6-1. ロース脂肪酸組成; 実験 2

\begin{tabular}{|c|c|c|}
\hline 脂肪酸組成 & 正常区 & 軟脂区 \\
\hline \multicolumn{3}{|l|}{ 全脂質 } \\
\hline C $14: 0$ & $1.48 \pm 0.20$ & $1.65 \pm 0.34$ \\
\hline C $16: 0$ & $25.19 \pm 1.01$ & $24.54 \pm 1.15$ \\
\hline C $16: 1$ & $3.46 \pm 0.18$ & $3.34 \pm 0.55$ \\
\hline C 18: 0 & $13.38 \pm 0.76$ & $13.58 \pm 0.67$ \\
\hline C $18: 1$ & $47.90 \pm 1.08 \mathrm{~A}$ & $44.26 \pm 0.63 \mathrm{~B}$ \\
\hline C $18: 2$ & $7.90 \pm 1.68 \mathrm{a}$ & $11.67 \pm 1.60 \mathrm{~b}$ \\
\hline T.U. & $59.96 \pm 1.75$ & $60.10 \pm 1.26$ \\
\hline $\mathrm{U} / \mathrm{S}$ & $1.50 \pm 0.11$ & $1.51 \pm 0.08$ \\
\hline \multicolumn{3}{|l|}{ 中性脂質 } \\
\hline C $14: 0$ & $1.62 \pm 0.18$ & $1.67 \pm 0.14$ \\
\hline C 16:0 & $25.42 \pm 0.90$ & $25.24 \pm 0.36$ \\
\hline $\mathrm{C} 16: 1$ & $3.68 \pm 0.20$ & $3.98 \pm 0.24$ \\
\hline C $18: 0$ & $13.34 \pm 0.46$ & $13.05 \pm 0.45$ \\
\hline C $18: 1$ & $49.25 \pm 1.16$ & $47.28 \pm 1.87$ \\
\hline C $18: 2$ & $6.68 \pm 1.52$ & $8.79 \pm 0.99$ \\
\hline T.U. & $59.61 \pm 1.31$ & $60.04 \pm 0.73$ \\
\hline $\mathrm{U} / \mathrm{S}$ & $1.48 \pm 0.08$ & $1.51 \pm 0.05$ \\
\hline \multicolumn{3}{|l|}{ 極性脂質 } \\
\hline C 16:0 & $5.92 \pm 0.46$ & $5.76 \pm 0.63$ \\
\hline $\mathrm{C} 16: 1$ & $22.64 \pm 1.19$ & $24.53 \pm 1.66$ \\
\hline C 18:0 & $12.58 \pm 0.23 \mathrm{a}$ & $13.62 \pm 0.71 \mathrm{~b}$ \\
\hline C $18: 1$ & $19.02 \pm 4.55$ & $17.28 \pm 1.70$ \\
\hline C $18: 2$ & $31.32 \pm 0.80$ & $29.73 \pm 2.01$ \\
\hline $\mathrm{C} 20: 4$ & $8.52 \pm 2.47$ & $9.09 \pm 0.56$ \\
\hline T.U. & $81.50 \pm 0.63$ & $80.62 \pm 0.92$ \\
\hline $\mathrm{U} / \mathrm{S}$ & $3.05 \pm 0.38$ & $2.86 \pm 0.11$ \\
\hline
\end{tabular}

平均值士標準偏差 T.U/; 全不飽和脂肪酸 $\mathrm{U} / \mathrm{S}$ : 全不飽和脂肪酸/全飽和脂肪酸
A, B, a, b ; 異符号間で有意差あり（A, B ; P $<0.01$ $\mathrm{a}, \mathrm{b} ; \mathrm{P}<0.05$ )

た。不飽和脂肪酸含量では腎臓周囲脂肪 $60.95 \%$, 皮下脂 肪内層 $60.90 \%$, 皮下脂肪外層 $65.55 \%$ となっており明ら かに皮下脂肪外層が高い值を示し, 皮下脂肪外層が最む 軟らかいと考えられた。

軟脂豚は触感で体脂肪組織（特に腹 ・ 背部, 腎臓周囲 の脂肪組織）が軟らかいものをいい, 異常肉質の一つと して以前から大きな問題となっている ${ }^{9)}$ 。軟脂豚が発生 する原因には, 給与飼料の質や量, 制限給餌, 環境温度 などがある。給与飼料の質によって体脂肪の性状が大き く影響を受けることはよく知られており，特に油脂の種 類之量が重要な要因であり, 油脂が多いほど脂質の生合 成が抑制され, 飼料中の不飽和脂肪酸が脂肪組織に多く
表 6-2. 蓄積脂肪脂肪酸組成; 実験 1

\begin{tabular}{|c|c|c|}
\hline 脂肪酸組成 & 正常区 & 軟脂区 \\
\hline \multicolumn{3}{|c|}{ 腎臓周囲脂肪 } \\
\hline C $14: 0$ & $1.75 \pm 0.36$ & $1.62 \pm 0.20$ \\
\hline C $16: 0$ & $25.79 \pm 1.00 \mathrm{~A}$ & $24.70 \pm 0.92 \mathrm{~B}$ \\
\hline C $16: 1$ & $2.71 \pm 0.67$ & $2.63 \pm 0.30$ \\
\hline C $18: 0$ & $12.83 \pm 0.57$ & $12.73 \pm 0.95$ \\
\hline C $18: 1$ & $45.01 \pm 0.97$ & $43.30 \pm 1.64$ \\
\hline C $18: 2$ & $11.28 \pm 1.25 \mathrm{~A}$ & $14.09 \pm 1.01 \mathrm{~B}$ \\
\hline C $18: 3$ & $0.65 \pm 0.10 \mathrm{a}$ & $0.94 \pm 0.05 \mathrm{~b}$ \\
\hline T.U. & $59.65 \pm 1.12 \mathrm{~A}$ & $60.95 \pm 1.91 \mathrm{~B}$ \\
\hline $\mathrm{U} / \mathrm{S}$ & $1.48 \pm 0.07$ & $1.57 \pm 0.13$ \\
\hline \multicolumn{3}{|c|}{ 皮下脂肪内層 } \\
\hline C $14: 0$ & $1.25 \pm 0.14$ & $1.30 \pm 0.19$ \\
\hline C $16: 0$ & $24.96 \pm 0.39 \mathrm{a}$ & $23.73 \pm 0.65 b$ \\
\hline C $16: 1$ & $1.35 \pm 0.53$ & $1.31 \pm 0.24$ \\
\hline C 18:0 & $15.73 \pm 1.21$ & $14.06 \pm 1.66$ \\
\hline C $18: 1$ & $43.71 \pm 1.24$ & $42.64 \pm 2.01$ \\
\hline C $18: 2$ & $12.31 \pm 0.83 \mathrm{~A}$ & $16.03 \pm 0.83 \mathrm{~B}$ \\
\hline C $18: 3$ & $0.71 \pm 0.09 \mathrm{a}$ & $0.93 \pm 0.14 b$ \\
\hline T.U. & $58.07 \pm 1.51 \mathrm{a}$ & $60.90 \pm 1.67 \mathrm{~b}$ \\
\hline $\mathrm{U} / \mathrm{S}$ & $1.39 \pm 0.09 \mathrm{a}$ & $1.60 \pm 0.12 \mathrm{~b}$ \\
\hline \multicolumn{3}{|c|}{ 皮下脂肪外層 } \\
\hline C $14: 0$ & $1.42 \pm 0.20$ & $1.34 \pm 0.05$ \\
\hline C $16: 0$ & $23.83 \pm 0.99 \mathrm{a}$ & $21.71 \pm 0.44 \mathrm{~b}$ \\
\hline C $16: 1$ & $2.47 \pm 0.67$ & $2.50 \pm 0.62$ \\
\hline C $18: 0$ & $12.10 \pm 0.06$ & $11.41 \pm 1.13$ \\
\hline C $18: 1$ & $46.99 \pm 1.36$ & $46.01 \pm 0.99$ \\
\hline C $18: 2$ & $12.48 \pm 0.52 \mathrm{~A}$ & $16.10 \pm 0.49 \mathrm{~B}$ \\
\hline C $18: 3$ & $0.71 \pm 0.02 \mathrm{a}$ & $0.94 \pm 0.20 \mathrm{~b}$ \\
\hline T.U. & $62.64 \pm 1.37 \mathrm{a}$ & $65.55 \pm 1.08 \mathrm{~b}$ \\
\hline $\mathrm{U} / \mathrm{S}$ & $1.68 \pm 0.09 \mathrm{~b}$ & $1.91 \pm 0.09 \mathrm{a}$ \\
\hline
\end{tabular}

平均値士標準偏差 T.U/; 全不飽和脂肪酸 $\mathrm{U} / \mathrm{S}$ : 全不飽和脂肪酸/全飽和脂肪酸
A, B, a, b ; 異符号間で有意差あり（A, B ; P $<0.01$ $\mathrm{a}, \mathrm{b} ; \mathrm{P}<0.05)$

蓄積し脂肪は軟らかくなる。また, 飼料中のリノール酸 は他の脂肪酸に比べて脂肪組織に優先的に蓄積しやす く, 体脂肪中のリノール酸含量の増加に伴って脂肪は軟 化するため, 体脂肪中のリノール酸含量が軟脂の有効な 指標となっている。環境温度の影響では, 環境温度が低 い場合には適温条件と比べてェネルギーの消費が激しく なり，さらに脂肪酸合成能は低下するため脂肪性状に影 響を与える。その結果，冬期には，夏期よりも不飽和脂 肪酸が高くなり, 軟質になりやすい。本実験の結果では, 
東北地方の $1 \sim 2$ 月の気温の中で飼育後期となり, 寒さ のために軟脂が発生したあのと考えられる。

\section{引 用 文 献}

1) Hilditch, T.P., C.H. LeA and W.H. Pedelty, Biochem. J. 33, 493-504, 1939.

2) Shorland, F.B. and P.B.D. Mare dela, J. Agri. Sci., 35, 33-38, 1968.

3) Greer, S.A.N., V.W. Hays, V.V. Speer, J.T. Mccall and E.G. Hammond, J. Animal Sci., 24, 1008-1013, 1965.

4) Koch, D.E., A.F. ParR and R.A. MERKEL, J. Food Sci., 33, 176-180, 1968.
5) Macgrath, W.S. Jr., G.W.V. NoOt, R.L. Gilbreath and H. Fisher, J. Nutr., 96, 461-466, 1968.

6) Fuller, M.F., W.R.H. Duncan and A.W. Boyne, J. Sci. Food Agr., 25, 205-210, 1974.

7）鈴木啓一・西 清志, 日本養豚学会誌， 29, 70-74, 1990.

8) Folch, J., M. Lees, Sloane-stanley G.H., J. Bio. chem., 226, 497-509, 1957.

9）入江正和, 畜産の研究，43, 1049-1055, 1989.

10）松尾 登・長谷川恭子編, 油脂, 女子栄養大学出 版部, 東京, 162-169, 1984.

\title{
Effects of Feed Restriction on Fatty Acid Composition of Meat and Adipose Tissues in Pig
}

\author{
Mitsuharu Ishida, Yuri Doudou, Keiichi Suzuki* and Toshirou Shimizu* \\ Miyagi Agricultural College, 2-2-1 Hatatate, Sendai-shi 982-0215 \\ * Miyagi Prefectural Animal Industry Experimental Station, \\ Iwadeyam-cho, Miyagi-ken 989-6445
}

In experiment 1 , effects of feed restriction on fatty acid composition and cholesterol level of meat (loin) and adipose tissues (subcutaneous fat and intermuscular fat) were investigated using 18 Land-race $\mathrm{x}$ White Yorkshire $\mathrm{x}$ Duroc barrows. The animals were allocated into three groups receiving full feeding (control), $80 \%$ and $60 \%$ of full feeding, respectively. Samples of loin ( $m$. longarisumus) were collected between 12 th and 13 th vertebrate 24 hours after slaughtering. There was no obvious effect of feed restriction on total lipids level in loin and the values were all similar among the groups. Proportions of palmitoleic and linoleic acids in total lipids in loin decreased with feed restriction although other fatty acids stayed at the same levels. While there was no large difference in loin neutral fatty acid composition among three groups, mrystic, palmitic, palmitoleic, linoleic acids, and degree of saturation in polar lipids, varied significantly $(\mathrm{P}<0.01)$ among the groups. Cholesterol levels tended to be lower with higher feed restrictions but no statistical significance was obtained. In experiment 2, loin, perirenal, subcutaneous and intermuscular fat taken from normal and soft fat barrows determined by palpation were subjected to fatty acid composition and cholesterol analyses. Loin samples of the soft fat pigs had a slightly lower total lipids level compared with those of the normal pigs but significantly higher $(\mathrm{P}<0.05)$ proportions of oleic and linoleic acids. This observation agrees with involvement of higher levels of oleic acid in occurrence of soft fat pigs. Compared with the normal pigs, the soft fat pigs had a largely lowered $(\mathrm{P}<0.01)$ cholesterol level.

Jpn. J. Swine Science, 36, $4: 152-159$

Key word : feed restriction, fatty acid composition, cholesterol, meat lipid, adipose tissues 